University of Nebraska - Lincoln

DigitalCommons@University of Nebraska - Lincoln

Studies on Neogogatea kentuckiensis (Cable, 1935) n. comb. (Trematoda: Strigeoidea: Cyathocotylidae)

Glenn L. Hoffman

US Fish and Wildlife Services

Clarence E. Dunbar

Eastern Fish Disease Laboratory

Follow this and additional works at: https://digitalcommons.unl.edu/usfwspubs

Part of the Aquaculture and Fisheries Commons

Hoffman, Glenn L. and Dunbar, Clarence E., "Studies on Neogogatea kentuckiensis (Cable, 1935) n. comb. (Trematoda: Strigeoidea: Cyathocotylidae)" (1963). US Fish \& Wildlife Publications. 103.

https://digitalcommons.unl.edu/usfwspubs/103

This Article is brought to you for free and open access by the US Fish \& Wildlife Service at DigitalCommons@University of Nebraska - Lincoln. It has been accepted for inclusion in US Fish \& Wildlife Publications by an authorized administrator of DigitalCommons@University of Nebraska - Lincoln. 


\title{
Studies on Neogogatea kentuckiensis (Cable, 1935) n. comb. (Trematoda : Strigeoidea : Cyathocotylidae)
}

\author{
Glenn L. Hoffman and Clarence E. Dunbar \\ Bureau of Sport Fisheries and Wildlife, Eastern Fish Disease Laboratory, \\ Kearneysville, West Virginia
}

\begin{abstract}
The cercaria of $N$. kentuckiensis was found in Anaplocamus dilatatus (Nitrocris d.) and Mudalia carinata. The metacercaria was found in all fishes examined from Opequon River, West Virginia, except Cottus bairdi which was also refractory to experimental infection.

Two species of Centrarchidae, four of Cyprinidae, three of Salmonidae, Etheostoma flabellare, Platypoecilus maculatus, and Trichogaster trichopterus were experimentally infected. The development of the metacercaria and cyst and effect on the fish are described.

The histopathology initially consists of hemorrhage and muscle necrosis about the metacercaria, followed by reorganization and formation of a loose connective tissue cyst.

The controversial adult names are discussed and an emendation of the genus Neogogatea is presented.
\end{abstract}

A survey of fishes from the Opequon River near Leetown, West Virginia, revealed a high population of the prohemistomulum metacercaria of Neogogatea kentuckiensis n. comb. (Mesostephanus $k$.). Likewise the snail host was found to be heavily parasitized.

The longifurcate cercaria of this trematode was described as Cercaria kentuckiensis by Cable (1935) from Goniobasis semicarinata in Kentucky. Anderson (1944) reported it from Goniobasis depygis in Indiana. Chandler and Rausch (1948) described the adult Neogogatea pandionis, a closely related worm, from the osprey, Pandion haliaetus carolinensis. Vernberg (1952) reported the cercaria from Goniobasis livescens in Indiana. Myer (1960) stated that the cercaria of Prohemistomum chandleri, also reported by Vernberg (1952), is probably Cercaria kentuckiensis. Hoffman (1959) reported the metacercaria from fish and an experimental adult from baby chicks as Neogogatea pandionis Chandler and Rausch. Myer (1960) redescribed the cercaria, infected fish with the cercaria, and reared the metacercaria to adult in baby chicks; he named the adult Mesostephanus kentuckiensis $\mathrm{n}$. comb. Our adult form, reared in baby chicks, which is identical with Myer's, is very similar to the adult described from the osprey by Chandler

Received for publication 11 December 1962. and Rausch (1948). Apparently the latter is either a closely related species of the same genus or the slight differences might be due to fixation artefacts. Our metacercaria has been deposited in the USNM Helminthological Collection as no. 56005 , the adult as no. 38887 .

\section{THE CERCARIA}

Since the cercaria has been adequately described by Cable $(1935,1938)$ and Myer (1960), no description will be given here except to note that it is a longifurcate, pharyngeate distome with characters of the subgroup (b) of subgroup Vivax, Sewell, 1922, as emended by Dubois (1951). One of the most striking characteristics of this cercaria is the presence of concretions in the intestinal ceca. We identified the cercaria with the aid of Chandler's (1953) key to the furcocercous cercariae.

The cercariae used in the experiments were recovered from two localities and two species of snails, both new host records but closely related to the known hosts Goniobasis livescens, G. semicarinata, and G. depygis. About 100 Anaplocamus dilatatus (Conrad) (Nitocris d.) collected at Glady Ford of Cheet River near Alpena, West Virginia, 6 October 1959, yielded five infected snails. On 10 October 1960, four infected snails were recovered from an uncounted number of snails from the same stream. 
On 29 October 1959, 340 Mudalia carinata (Bruguire) were collected from the Opequon River near Leetown, West Virginia, of which $4.1 \%$ were infected. On 22 April 1960, 300 and on 3 October 1960, 400 were collected from the same source but none were infected.

These snails, infected or not, remained alive for 3 weeks or more in small containers although they were never observed to feed and no reproduction occurred. We know of no one who has reared any of these species in the laboratory.

Each of fourteen infected snails was kept in a 6-cm petri dish and an estimate made of daily cercarial production (based on partial counts). The daily production was much lower than that of other strigeoids studied by us (Hoffman, 1956; Hoffman and Hundley, 1957; Hoffman, 1958), but they produced cercariae for a longer period of time-up to 44 days. The 14 snails produced from 0 to 200 cercariae (usually 10 to 50 ) daily for 15 to 44 days with a total production of 40 to 1,520 (average 609) for each. Suboptimal conditions for the snail probably influenced cercarial production.

The evening cercarial emergence (from 4:00 PM to 8:00 AM) as recorded by Myer (1960) was verified with the 14 infected snails. Three lots of 20,60 , and 10 cercariae were observed for longevity-17 survived $32 \mathrm{hr}$ and 2 survived $48 \mathrm{hr}$. Therefore, maximum longevity is approximately $48 \mathrm{hr}$. The exact age of the cercariae used was not known because they had emerged from the snail during the previous 16-hr period.

\section{THE METACERCARIA}

As with most strigeoid worms the metacercarial stage of Neogogatea kentuckiensis is the one most likely to come to attention. The known natural host, possibly the osprey, is seldom available and although $4 \%$ of the snail hosts were infected in one collection, none were found infected in subsequent collections. Contrarily, the prohemistomulum metacercariae could be obtained any time during the 3-year period the fish could be collected in the endemic area.

The metacercariae were found in the musculature and usually were found by teasing a small portion apart under the dissecting microscope. Most of the cysts were opaque white but a few had scattered black pigment cells in the outer layer. Pepsin digestion (pep$\sin 0.5 \%$, hydrochloric acid $0.5 \%$ at $39 \mathrm{C}$ ) was used for freeing cysts for total counts from fish that were lightly infected and to obtain quantities of metacercariae for experimental feeding. Metacercariae survived pepsin digestion but were still in the cysts of parasite origin. They readily excysted in trypsin solution ( $0.1 \%$ trypsin, $1 \%$ sodium bicarbonate) in about $15 \mathrm{~min}$ at $39 \mathrm{C}$. The mature metacercaria is described under "Development," p. 740 .

\section{NATURAL INFECTIONS}

Fishes were collected by seine and line fishing at various times, but mostly during the summers (1959-1960). A few were collected during the winter. No seasonal incidence of infection in the fish was apparent and we believe that the metacercaria survives more than one season because very few dead cysts were encountered and mature metacercariae were present in early spring. The most readily available fish, fallfish, were nearly $100 \%$ infected and usually with numerous metacercariae-up to 2,000 each. Although not all species of fish were infected, there was no indication of nonsusceptibility except in the case of Cottus bairdi. This fish was not infected naturally and we could not infect it experimentally. Cottus is scaleless and has a tougher skin than the rest of the fishes examined.

The fishes examined and those infected are as follows: Ambloplites rupestris (rockbass), 2 of 2; Campostoma anomalum (stoneroller), 0 of 1; Carassius auratus (goldfish), 0 of 1; Catostomus commersoni (black sucker), 0 of 3; Cottus bairdi (miller's thumb), 0 of 5; Exoglossum maxillingua (cutlips minnow), 3 of 3 ; Lepomis cyanellus (green sunfish), 0 of 6 ; L. gibbosus (common sunfish), 1 of $1 ; L$. macrochirus (bluegill), 1 of 10; Micropterus salmoides (largemouth bass), 0 of 7; Notropis cornutus (common shiner), 3 of 6; Notemigonus crysoleucas (golden shiner), 0 of 7 ; Rhinichthys a. atratulus (blacknose dace), 0 of 7 ; R. c. cataractae (longnose dace), 0 of 2 ; Semotilus atromaculatus (creek chub), 3 of 5 ; and Semotilus corporalis (fallfish), 25 of 26. 


\section{EXPERIMENTAL INFECTIONS}

During the fall of 1959 small fishes were exposed to the cercariae from naturally infected snails in just enough water to maintain the fish. The fish were observed often during the 1st day to note any signs of distress. Following that, fish were selected at intervals to observe the development of the metacercaria, the cyst of parasite origin, and the host tissue reaction.

\section{Centrarchidae}

Fourteen bluegills (Lepomis macrochirus) and one green sunfish (L. cyanellus), 1 to 2 inches in length, were exposed to crops of cercariae in groups of one to six fish. All became infected.

These fish began to show irritation almost immediately after placing the cercariae with them. The signs consisted of turning on their sides and "shimmying" against the bottom of the aquarium. This action was repeated each time a new batch of cercariae was added. Within $30 \mathrm{~min}$ ecchymoses could be seen in the skin and muscle, presumably where the cercariae had penetrated. In light to moderate infections (ca. 50 cercariae per fish) the symptoms lasted only 3 to $4 \mathrm{hr}$ and the ecchymoses disappeared. In some heavy infections (300 to 400 cercariae per fish) the symptoms lasted as long as 15 days; the ecchymoses persisted for several days. In some instances the fish turned splotchy dark, the fins became "pinched," and the fish rested upright on the bottom. Often when disturbed, they demonstrated the irritation motions displayed earlier. In one instance, a bluegill, 1.5 inches in length, was killed in $1 \mathrm{hr}$ by 540 cercariae. Juvenile and mature metacercariae were recovered from surviving fish.

\section{Cyprinidae}

Three Notropis sp., one Pimephales promelas, four Rhinichthys atratulus, and two Semotilus atromaculatus were exposed to the cercariae and became infected. One S. atromaculatus, ca. 2 inches long, with many ecchymoses easily seen in the musculature was observed for 8 days. At 3 days the ecchymoses could still be seen but were lighter in color and at 8 days no evidence of the hemorrhages could be seen. These fish seemed to be in dis- tress during cercarial penetration and flashed on their sides toward the bottom but no shimmying on their sides as in the bluegills was observed.

\section{Salmonidae}

Two 6-inch eastern brook trout (Salvelinus fontinalis), three 6-inch rainbow trout (Salmo gairdneri), and one 8-inch brown trout (Salmo trutta) were exposed to cercariae. Normal metacercariae were recovered from all.

Three lots of 50, 7, and 10 rainbow trout sac fry, respectively, ca. 2 weeks old, were exposed to 30,40 , and 60 cercariae each. It was noticed under the dissecting microscope that part of the cercarial tail, as well as the body, had penetrated. We did not notice whether this occurs in older fish also. This is in contrast to our observation of the shedding of the tail by penetrating cercariae of Diplostomum baeri eucaliae. All of these fishes were killed by the cercariae in 1.5 to $2.5 \mathrm{hr}$ except for four of those exposed to 30 cercariae which were sacrificed at 7 and 10 days. Before death they tried to rub their sides with frantic dashes to the bottom of the container. Within $20 \mathrm{~min}$ ecchymoses could be seen in the musculature. Hemorrhages from migrating cercariae released almost all of the blood in these small fish, and at $2 \mathrm{hr}$ in some that were otherwise motionless, the bloodless heart could be seen beating under the dissecting scope. Death was attributed to the hemorrhages.

\section{Cottidae}

Three fish, miller's thumb (Cottus bairdi), 2 to 3 inches long, were exposed to cercariae in the same aquaria as some of the other fishes which became infected. None displayed distress. No live metacercariae were recovered from them, but one dead metacercaria was found. Cottus has no scales and the skin is very tough for a fish of this size. Because of this experimental evidence, and not finding any naturally infected Cottus, it is assumed that this fish is refractory to the infection.

\section{Miscellaneous fishes}

One fantail darter (Etheostoma flabellare), three blue and one red platy (Platypoecilus maculatus), and one three-spot gourami (Trichogaster trichopterus) were exposed to the cercariae. Both blue and red platy shimmied 
on their sides toward the bottom, but no hemorrhagic spots were noticed. The shimmying lasted about $0.5 \mathrm{hr}$ at which time they rested, ventral side down, on the bottom. Normal metacercariae were recovered from all.

\section{DEVELOPMENT OF THE METACERCARIA AND THE CYST}

(Measurements in microns)

Penetration and migration: The cercariae penetrate and move into the musculature very quickly.

Two to three $h r$ : Most of them have localized and some have already secreted a cyst 7 to 14 thick. This early thick cyst appears to have two layers, a thin outer layer about 2 thick and a less dense but thicker inner layer about 12 thick. The inner layer appears to liquefy, usually within a few hours, but was seen as late as 6 days; the outer part remains intact.

One to two days: The parasite is 180 to 250 by 150 to 215 (average of six: 224 by 184) and usually pyriform but may assume ameboid shapes. The oral sucker is 48 in diameter. Very little internal detail can be seen because of the numerous internal large globules ( 5 to 60 in diameter). It is possible that these large globules are cystogenous in nature because they can not be seen in older metacercariae but they may be related to the liquefaction process of cercarial metamorphosis as described by Szidat (1929) for Cotylurus cornutus. In cross sections our metacercariae appear "blown-up" as if the parenchyma had become extremely edematous. This is very similar to Szidat's illustrations, but no giant cells, such as he described, could be found in this stage or later. The aforementioned globules could not be seen in the cross sections. Several specimens demonstrated many globs of liquid exuding from the entire surface. We believe this was cystogenous material exuding from many subcuticular cystogenous glands and similar to that of Posthodiplostomum minimum as described by Hoffman (1958). In one instance, the excretory tubules could be seen and these small tubules made the same pattern as the reserve excretory system of the mature metacercaria. We were not able to distinguish separate primary and reserve excretory systems in this material. The parasite cyst is 180 to
260 by 180 to 220 (average 231 by 210 ) in diameter. The formation of the cysts does not proceed at equal pace; some were composed of two layers of 1.5 each. The metacercaria is easily removed from the new cyst mechanically.

Three to seven days: The metacercaria is no longer pear-shaped but oval and is wider than long. Two measured 260 by 180 and 340 by 440. The oral sucker is 46 by 69 (average of three), the pharynx 26 by 15 and the esophagus is 35 long. The aforementioned large globules are still present in some worms. The parasite cyst is 275 by 234 (average of 12) in diameter. The thickness of the parasite cyst varies from 1 to 10 .

Eight to twenty days: Very little change occurs. Two averaged 230 by 200 in size. The ventral sucker can be seen in the living worm. The "W"-shaped excretory bladder is not apparent in freshly dissected worms unless they are flattened severely or are observed in $2 \%$ sodium chloride; very few granules are present in the bladder. The parasite cyst of three individuals was 277 by 240 at 18 days; the cyst wall was 5 to 7 thick.

Twenty-two to 28 days: The metacercaria remains about the same size but the "W"shaped excretory bladder becomes more obvious as the excretory granules increase in size and number. At 25 days the granules have reached their maximum size, 2.5 in diameter. The metacercariae of 25 days and younger (five fish) did not survive pepsin digestion. Of two 26-day-old infections, metacercariae of one survived. Those of one 27day-old infection did not survive, and of two 28-day-old infections, larvae of one survived. At 28 days Myer (1960) found the metacercariae to be infective for the first time for baby chicks. This coincides with excretory granule development and the ability to survive pepsin digestion. The excretory bladder can be seen through the cyst of parasite origin, but the host cyst (connective tissue) must be removed mechanically, or by pepsin digestion, before it can be seen. The most striking characteristic of this strigeoid metacercaria is the "W"-shaped excretory bladder (Fig. 2) described by Hoffman (1960). In reflected (direct) light under the dissecting microscope the excretory granules are opaque-white and cause the bladder to stand out. With trans- 


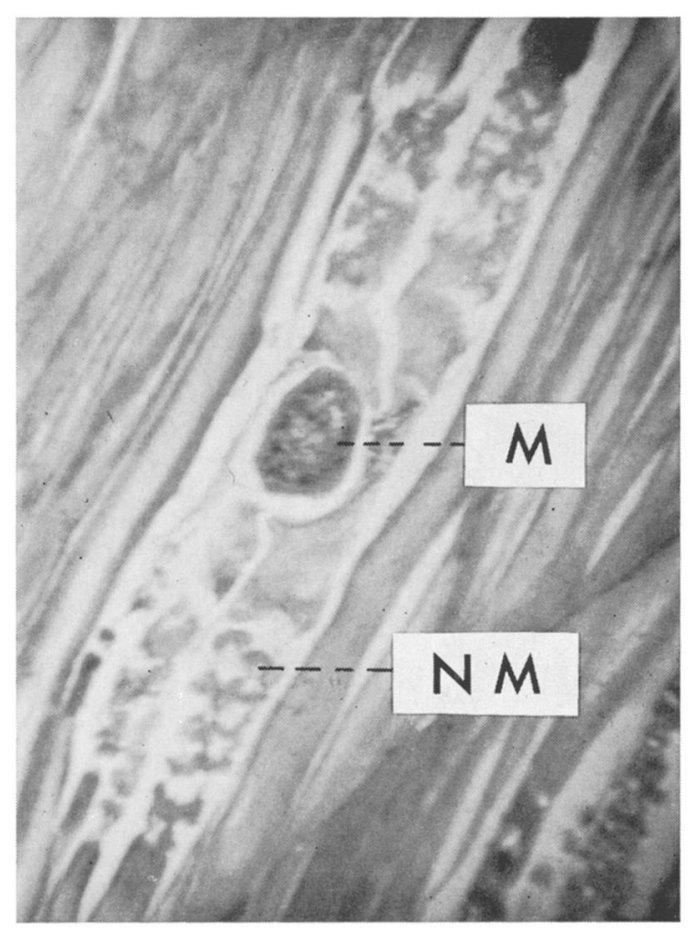

Figure 1. Fish infected with Neogogatea kentuckiensis, $24 \mathrm{hr}$, magnification $100 \times . \mathrm{M}=$ metacercaria, $\mathrm{NM}=$ necrotic muscle.

mitted light the opaque granules give the bladder a black appearance. Sixteen cysts of parasite origin were 260 to 350 by 220 to 270 (average 301 by 247) in diameter.

Fifty-one days: Three were studied. No further development could be seen and they survived pepsin digestion. Three parasite cysts averaged 293 by 277 .

\section{HISTOPATHOLOGY}

Helminthic invasion of fish tissue usually does not incite marked inflammatory response but the parasite, if localized long enough, usually becomes encapsulated by connective tissue (Bauer, 1958). There are no records of the demonstration of toxic effect caused by helminths in fish tissue. Invasion by $\mathrm{Neo}$ gogatea kentuckiensis, however, causes considerable degeneration of muscle fibers adjacent to it. We were not able to determine if this damage was caused by toxic materials or simple mechanical damage.

Following are the results of our histopathological studies:

Less than $1 \mathrm{hr}$ : No demonstrable damage.
One hr: An area of muscle necrosis 250 to $450 \mu$ in diameter around the cercariae. Some hemorrhage around cercariae.

Four hr: Muscle necrosis persists; one necrotic area measured 300 by $600 \mu$. Parasite now localized and the cyst of parasite origin is being formed.

Twenty-four $h r$ (Fig. 1): Cyst of parasite origin now present, much necrosis and hemorrhage present.

Six days: Small amount of loose connective tissue surrounding parasite cyst. Muscle necrosis less evident.

Ten days: Apparently same as 6 days.

Sixteen days: Muscle appears to be repaired. Loose connective tissue cyst of host origin is 7 to $12 \mu$ thick.

Nineteen days: Loose connective tissue cyst of host origin is 9 to $48 \mu$ thick.

Twenty-eight days: Host cyst is now more dense and 5 to $7 \mu$ thick. Usually this is nonpigmented but some naturally infected fish had a few black cysts.

\section{DISCUSSION}

There is little doubt about the identity of Cercaria kentuckiensis as described by Cable (1935) and reported by Anderson (1944), Vernberg (1952), and Myer (1960). Likewise, there is no confusion regarding the experimental metacercaria of Hoffman (1959), Myer (1960), and this paper. The cercaria was described first; therefore, the specific name of this worm must be kentuckiensis. The generic name of the adult is controversial, however. Dr. G. Dubois (1961, pers. comm.) believes that Neogogatea pandionis (Chandler and Rausch, 1948) and our worm, which he has seen, are identical. Of this we are not certain. Myer (1960) believes that his experimental adult and ours are identical, but are not $N$. pandionis-he believes that the worm belongs in the genus Mesostephanus mainly because of the presence of a vaginal sphincter (Figs. 3, 4).

Morphologically, adults of the genera Neogogatea, Mesostephanus, and Prohemistomum are grossly similar although the latter is larger and broader. The holdfast of Neogogatea is linguiform but is small and oval in Mesostephanus and Prohemistomum. The vitellaria of Neogogatea are in the holdfast area but surround the holdfast of Mesostephanus and Prohemistomum. Neogogatea kentuckiensis possesses a vaginal sphincter (this can not be determined in N. pandionis and N. bubonis-possibly because of poor fixation of the type specimens); 

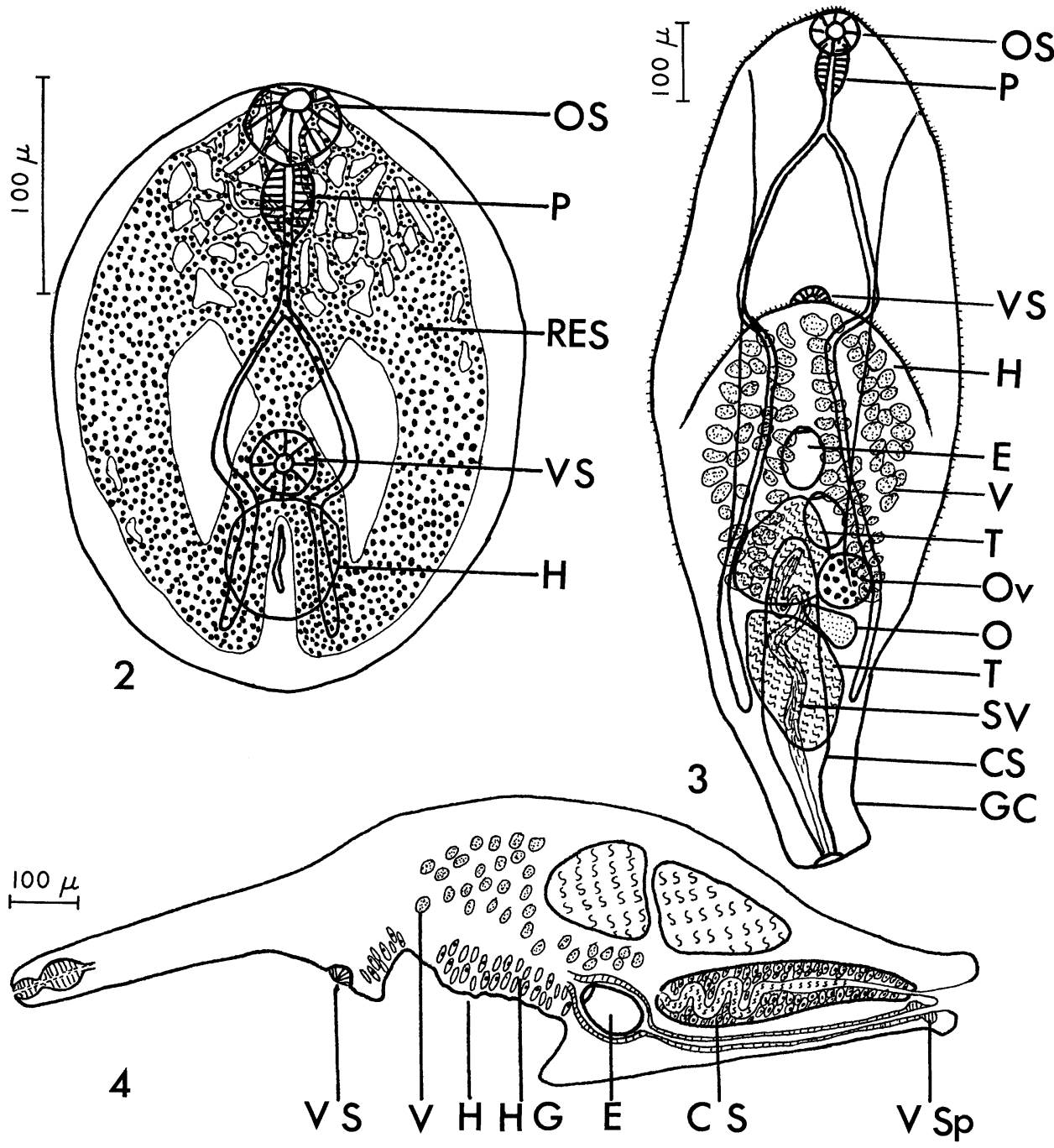

Figures 2 to 4.

All figures are of Neogogatea kentuckiensis.

Figure 2. Mature (fully developed) metacercaria.

Figure 3. Eleven-day-old experimental adult from baby chick. Drawn with aid of microprojection. Figure 4. Composite drawing made from sagittal sections of two experimental adults.

Abbreviations: CS, cirrus sac; E, egg in uterus; GC, genital cone; $\mathrm{H}$, holdfast organ; $\mathrm{HG}$, holdfast gland; O, ootype; OS, oral sucker; Ov, ovary; P, pharynx; RES, reserve excretory system; SV, seminal vesicle; T, testis; V, vitellaria; VS, ventral sucker; VSp, vaginal sphincter.

Mesostephanus does possess the sphincter, but Prohemistomum does not. Neogogatea and Mesostephanus possess feeble ventral suckers but that of Prohemistomum is well developed. The ventral sucker of the metacercaria of the present worm is prominent, however.

Little is known concerning other cercariae of these two genera, but N. kentuckiensis fits into the subgroup (b) of subgroup Vivax (Sewell, 1922) emended by Dubois (1951), which contains freshwater forms found in Melaniidae. Contrarily, the known cercariae of Mesostephanus fit into subgroup (a) of subgroup Vivax (op. cit.) which contains at least one freshwater form, but also all of the known cercariae of Mesostephanus; these 
are found in marine cerithiid snails. In the latter group are the cercariae of Mesostephanus sp. (C. utriculata Lutz, 1933), Mesostephanus appendiculatoides (cf Hutton and SogandaresBernal, 1960) and Mesostephanus appendiculatus (cf Martin, 1961). This information supports the thesis that the present worm does not belong to the genus Mesostephanus. The subgroups (a) and (b) of Dubois (1951) are not well separated on the basis of the morphological details compared. However, we believe the biological data concerning the different snail hosts to be extremely helpful, i.e., Neogogatea in melaniid freshwater snails and Mesostephanus in cerithiid marine snails.

We believe that the present worm fits the generic description of Neogogatea except for the presence of a ventral sucker which was overlooked by the original describers; it is very difficult to demonstrate in whole mounts of the adults. We, therefore, emend the description of the genus to include these characters.

\section{Neogogatea (Chandler and Rausch, 1947)}

Generic diagnosis: Cyathocotylidae. Body elongate; broad and leaflike, with anterior edges usually slightly rolled ventrally; constricted into a short truncated cone posteriorly. Oral sucker terminal. Prepharynx very short, almost absent. Pharynx larger than oral sucker. Esophagus short, about equal to pharynx in length. Ceca sinuous to level of ventral sucker, usually converging slightly before ending at posterior $1 / 8$ body. Ventral sucker poorly developed, mesial in about anterior third of body. Holdfast organ mesial, in middle third of body, immediately following and sometimes overlapping ventral sucker, large in ventral view, but shallow from side view, elongate, linguiform, concave. Genital pore at posterior end of body, followed by short genital atrium. Testes large, tandem, intercecal, approximately between posterior $3 / 7$ to $6 / 7$ of body. Cirrus sac claviform, extending about from level of anterior testis to genital atrium; containing convoluted seminal vesicle in anterior $1 / 4$ to $1 / 2$, glandular pars prostatica in posterior $1 / 2$ and cylindrical cirrus in posterior $1 / 4$. Ovary smaller than testes, intertesticular and/ or dextral or sinistral to testes. Uterus ascending intercecally about to equator of body, descending along cirrus sac to terminate in weak vaginal sphincter connecting with genital atrium. Eggs large, operculate. Vitelline follicles large, confined to region of holdfast organ anteriorly, extending ventrally to posterior testis.

Type species: Neogogatea bubonis Chandler and Rausch, 1947, in Bubo virginianus; Wisconsin.

Other species: Neogogatea pandionis Chandler and Rausch, 1948, in Pandionis haliaetus carolinen- sis; Wisconsin. N. kentuckiensis (Cable, 1935), experimentally in baby chicks; cercaria in Goniobasis livescens, G. semicarinata, G. depygis, Anaplocamus dilatatus, and Mudalia carinata, flamecell formula $2[(3+3+3)+(3+3+3)]$; prohemistomulum metacercaria in many fish (Myer, 1960; this paper).

\section{ACKNOWLEDGMENTS}

The Glady Fork snails were kindly given by Dr. John Hall, University of West Virginia, and the snails were identified by Dr. J. P. E. Morrison, Smithsonian Institution. Dr. Georges Dubois and Dr. Donal Myer have studied our slides and made valuable suggestions. Mr. Bob Putz has critically reviewed the manuscript.

\section{LITERATURE CITED}

Anderson, D. J. 1944. Studies on C. szidati sp. nov., a new furcocercous cercaria of the Vivax type. J. Parasit. 30: 264-268.

BAUER, O. N. 1958. Relationships between host fishes and their parasites. In Dogiel, Petrushevski, and Polyanski, Parasitology of fishes. English ed. Oliver and Boyd, Edinburgh, $384 \mathrm{p}$.

CABLE, R. M. 1935. Cercaria kentuckiensis n. sp., first representative of the Vivax group known to occur in the United States. J. Parasit. 21: 436.

- 1938. Cercariae of Indiana. I. A preliminary note on larval trematodes from McCormick's Creek with a description of three new species. Proc. Indiana Acad. Sci. 47: 227-228.

Chandler, A. C. 1953. Key to the furcocercous cercariae. Mimeographed, Rice University.

- AND R. RAUSCH. 1948. A contribution to the study of certain avian strigeids (Trematoda). J. Parasit. 34: 207-210.

Duвors, G. 1951. Nouvelle clé de détermination des groupes systématiques et des genres de Strigeida Poche (Trématoda). Rev. Suisse Zool. 58: 639-691.

Hofrman, G. L. 1956. The life cycle of Crassiphiala bulboglossa (Trematoda: Strigeida). Development of the metacercaria and cyst, and effect on the fish hosts. J. Parasit. 42: 435-444.

- 1958. Experimental studies on the cercaria and metacercaria of a strigeoid trematode, Posthodiplostomum minimum. Exp. Parasit. 7: 23-50.

- 1959. Studies on the life cycle of Neogogatea pandionis Chandler and Rausch, 1948 (Trematoda: Strigeoidea-Cyathocotylidae). J. Parasit. 45: 19.

- 1960. Synopsis of Strigeoidea (Trematoda) of fishes and their life cycles. Fishery Bull. 175, Vol. 60, Fish and Wildlife Service.

- and J. Hundley. 1957. The life-cycle of Diplostomum baeri eucaliae n. subsp. (Tre- 
matoda : Strigeida) J. Parasit. 43: 613-627.

Hutton, R. F., and F. Sogandares-Bernal. 1960. Preliminary notes on the life-history of Mesostephanus appendiculatoides (Price, 1934) Lutz, 1935. Bull. Marine Sci. Gulf and Caribbean 10: 234-236.

Martin, W. E. 1961. Life cycle of Mesostephanus appendiculatus (Ciurea, 1916) Lutz, 1935 (Trematoda : Cyathocotylidae). Pacific Sci. 15: 278-281.

Myer, D. 1960. On the life history of Mesostephanus kentuckiensis (Cable, 1935) n. comb. (Trematoda : Cyathocotylidae). J. Parasit. 46: 819-832.

Sewell, R. B. S. 1922. Cercariae indicae. In- dian J. Med. Res. 10 (Suppl.): 1-370.

SzidAt, L. 1929. Beiträge zur Kenntnis der Gattung Strigea (Abildg.). I. Allgemeiner Teil: Untersuchungen über die Morphologie, Physiologie und Entwicklungsgeschichte der Holostomiden nebst Bemerkungen über die Metamorphose der Trematoden und die Phylogenie derselben. Ztschr. Parasitenk., Berl. I (4-5): 612-687.

VernberG, W. B. 1952. Studies on the trematode family Cyathocotylidae Poche, 1926, with a description of a new species of Holostephanus from fish and the life history of Prohemistomum chandleri n. sp. J. Parasit. 38: 327-340. 